\title{
FAKTOR-FAKTOR YANG MEMPENGARUHI KEJADIAN SKABIES DI PONDOK PESANTREN MLANGI NOGOTIRTO GAMPING SLEMAN YOGYAKARTA
}

\author{
Hilma UD ${ }^{1}$, Ghazali L ${ }^{2}$ \\ ${ }^{1}$ Mahasiswa Fakultas Kedokteran Universitas Islam Indonesia \\ ${ }^{2}$ Departemen Ilmu Kesehatan Masyarakat Fakultas Kedokteran Universitas Islam Indonesia
}

\begin{abstract}
ABSTRAK
Latar Belakang:

Pesantren merupakan salah satu tempat yang memiliki faktor risiko tinggi untuk terjadinya penyakit skabies. Prevalensi skabies yang masih tinggi dapat dipengaruhi faktor risiko seperti rendahnya tingkat ekonomi, higiene yang buruk, hunian padat, promiskuitas seksual, tingkat pengetahuan, usia dan kontak dengan penderita.
\end{abstract}

\section{Tujuan:}

Mengetahui hubungan tingkat pengetahuan, frekuensi kontak tidak langsung, tingkat higienitas dan kepadatan hunian dengan kejadian skabies.

\section{Metode:}

Penelitian ini bersifat noneksperimental dengan desain potong lintang. Sampel diambil dengan teknik total sampling dengan jumlah 53 responden. Analisis data menggunakan uji Chi Square dan uji alternatif Fisher ( $p<0,05$; CI 95\%) serta Analisis Regresi Logistik.

\section{Hasil:}

Hasil penelitian didapatkan $29(54,7 \%)$ responden terdiagnosis skabies dan $24(45,3 \%)$ tidak terdiagnosis skabies. Tingkat pengetahuan memiliki hubungan terhadap kejadian skabies dengan $p=0,038$; RP 4,261 (CI 0,684-26,543). Frekuensi kontak tidak langsung berhubungan terhadap kejadian skabies dengan $p=0,008$; RP 1,917 (CI 1,205-3,049). Tingkat higienitas tidak memiliki hubungan terhadap kejadian skabies dengan $p=0,4 ; \mathrm{RP}$ 1,247 (CI 0,732-2,123). Kepadatan hunian tidak memiliki hubungan dengan kejadian skabies.

\section{Simpulan:}

Terdapat hubungan yang bermakna antara tingkat pengetahuan dan frekuensi kontak tidak langsung terhadap kejadian skabies, tetapi tidak terdapat hubungan yang bermakna antara tingkat higienitas dan kepadatan hunian dengan kejadian skabies.

Kata Kunci: Skabies, tingkat pengetahuan, frekuensi kontak tidak langsung, tingkat higienitas, kepadatan hunian, pondok pesantren. 


\section{ABSTRACT}

\section{Background:}

Boarding school is one of places which has high risk factors to skabies infection.The prevalence of skabies are still hige that may be influenced by various factors namely the low level of economic, poor hygiene, crowded communities, sexual promiscuity, level of knowledge, age and contact with skabies-infected person.

\section{Objectives:}

This study was to find out the relationship between the level of knowledge, frequency of indirect contact, the level of higyene and crowded communities with skabies infection and contagion.

\section{Method:}

This study is a nonexperimental research which cross-sectional study design. Samples were taken by total sampling technique with 53 respondens. Data were analysed using Chi Square Test and Fisher Alternative Test ( $p<0,05$; CI 95\%) followed also with Regression Logistic Analytic.

\section{Results:}

This study found $29(54,7 \%)$ respodents who were skabies-infected and $24(45,3 \%)$ who were not. There was a relation between level of knowledge and skabies with $p=0,038 ; R P$ 4,261 (CI 0,68426,543). There was a relation between frequency of indirect contact and skabies with $p=0,008 ; R P$ 1,917 (CI 1,205-3,049). There was no relation between level of hygiene and skabies with $p=0,4$; $R P$ 1,247 (CI 0,732-2,123). There was also no relation between crowded communities and skabies.

\section{Conclusion:}

There was a significant relationship between the level of knowledge and frequency of indirect contact with skabies infection. In contrary, there was no significant relationship between the level of hygiene and crowded communities with skabies infection.

\section{Keywords:}

Skabies, the level of knowledge, frequency of indirect contact, the level of hygiene, crowded communities, boarding school.

\section{PENDAHULUAN}

Skabies adalah penyakit infeksi menular yang disebabkan oleh infeksi dan sensitisasi oleh tungau Sarcoptes scabei var hominis (Sarcoptes sp.) beserta produknya. ${ }^{1}$

Skabies dapat dipengaruhi oleh beberapa faktor risiko seperti rendahnya tingkat ekonomi, higienisitas yang buruk, hunian padat, promiskuitas seksual, tingkat pengetahuan, usia dan kontak dengan penderita baik langsung maupun tidak langsung. ${ }^{2}$

Tanda kardinal penyakit skabies yaitu pertama gatal di malam hari karena aktivitas tungau skabies meningkat di suhu yang lebih lembab dan panas. Kedua, 
penyakit ini menyerang manusia secara kelompok, misalnya dalam sebuah keluarga biasanya seluruh anggota akan terkena infeksi ini. Ketiga, adanya terowongan pada tempat-tempat predileksi yang berwarna putih atau keabu-abuan, berbentuk garis lurus atau berkelok dan pada ujung terowongan ditemukan atau vesikel. Keempat, menemukan tungau yang merupakan hal penentu diagnostik. ${ }^{2}$

Prevalensi penyakit skabies di Indonesia masih cukup tinggi karena termasuk negara tropis. Penyakit ini banyak ditemukan pada tempat dengan penghuni padat seperti asrama tentara, penjara dan pondok pesantren. Tempat yang berpenghuni padat ditambah lingkungan yang tidak terjaga kebersihannya akan memudahkan transmisi dan penularan tungau skabies. ${ }^{3}$

Penelitian Saad (2008) mendapatkan prevalensi skabies sebesar $43 \%$ di Pesantren An-Najach Magelang ${ }^{4}$. Sedangkan pada penelitian Khotimah (2013) mendapatkan prevalensi skabies di Pondok Pesantren Al-Bahroniyyah Ngemplak Demak sebesar 36,3\%. Hasil tersebut menunjukkan bahwa kejadian skabies masih sering di lingkungan pesantren. ${ }^{5}$
Pondok pesantren An-Nasyath di Mlangi Sleman Yogyakarta merupakan salah satu pondok pesantren yang besar di Kabupaten Sleman. Salah satu orang santri yang menderita skabies maka dapat menularkan penyakitnya pada santri lainnya. Jumlah penderita skabies semakin meningkat dari waktu ke waktu. Penyakit ini dapat menurunkan produktivitas para santri karena rasa gatal terutama pada malam hari dapat mengganggu konsentrasi belajar dan mengurangi kenyamanan tidur sehingga perlu dilakukan penelitian tentang faktor-faktor yang mempengaruhi penularan penyakit skabies. Penelitian ini diharapkan dapat digunakan sebagai acuan penanggulangan penyakit skabies agar tidak terjadi secara terus-menerus.

\section{METODE}

Penelitian ini bersifat noneksperimen dengan desain survey cross sectional. Populasi penelitian adalah santri putra dan santri putri Pondok Pesantren An- Nasyath Mlangi Sleman Yogyakarta dengan teknik total sampling sehingga seluruh anggota populasi diikutkan dalam penelitian. Kriteria inklusinya adalah Santri Pondok Pesantren An-Nasyath yang berada di pesantren selama penelitian dan bersedia menjadi responden penelitian. Kriteria 
Tabel 1. Distribusi Karakteristik Sampel

\begin{tabular}{llcc}
\hline No & Karakteristik sampel & $\mathrm{n}$ & $\%$ \\
\hline 1. & Jenis kelamin & & \\
& a. Laki-laki & 24 & 45,3 \\
& b. Perempuan & 29 & 54,7 \\
\hline & Total & 53 & 100 \\
\hline 2. & Usia & & \\
& a. $\leq 17$ tahun & 34 & 64,2 \\
& b. $>17$ tahun & 19 & 35,8 \\
\hline & Total & 53 & 100 \\
\hline 3. & Skabies & & \\
& a. Ya & 29 & 54,7 \\
& b. Tidak & 24 & 45,3 \\
\hline & Total & 53 & 100 \\
\hline 4. & Tingkat Pengetahuan & & \\
& a. Tinggi & 7 & 13,2 \\
& b. Rendah & 46 & 86,8 \\
\hline & Total & 53 & 100 \\
\hline 5. & Frekuensi Kontak & & \\
& a. Tinggi & 19 & 35,8 \\
& b. Rendah & 34 & 64,2 \\
\hline & Total & 53 & 100 \\
\hline 6. & Tingkat Higienitas & & \\
& a. Baik & 21 & 39,6 \\
& b. Buruk & 32 & 60,4 \\
\hline & Total & 53 & 100 \\
\hline 7. & Kepadatan Hunian & & \\
& a. Padat & 0 & 0 \\
b. Tidak padat & 53 & 100 \\
\hline & Total & 53 & 100 \\
\hline & & \\
& & & \\
& &
\end{tabular}

eksklusi yaitu responden yang tidak mengisi kuisioner secara lengkap.

Instrumen penelitian yang digunakan yaitu menggunakan kuisioner pada santri yang menderita skabies yang telah didiagnosis skabies oleh dokter dan checklist serta wawancara dengan pengasuh pesantren.

Analisis yang digunakan dalam penelitian meliputi analisis univariat, bivariat dan multivariat. Data-data yang diperoleh akan dianalisis menggunakan uji Pearson Chi Square dan uji alternatif Fisher.

\section{HASIL DAN PEMBAHASAN}

Distribusi karakteristik santri di Pondok Pesantren An-Nasyath ditampilkan pada Tabel 1.

Distribusi karakteristik responden berdarkan tingkat pengetahuan dapat dilihat pada Tabel 2 berikut ini.

Analisis antara tingkat pengetahuan dengan kejadian skabies menggunakan uji alternatif yaitu uji Fisher didapatkan $p$ value $(<0,05)$ sebesar 0,038 yang berarti terdapat hubungan bermakna. Rasio

Tabel 2. Distribusi berdasarkan tingkat pengetahuan

\begin{tabular}{lcccccc}
\hline & \multicolumn{4}{c}{ Skabies } & \multirow{2}{*}{ Jumlah } \\
\cline { 2 - 6 } & \multicolumn{2}{c}{ Ya } & \multicolumn{2}{c}{ Tidak } & & \\
\cline { 2 - 6 } & $\mathrm{N}$ & $\%$ & $\mathrm{~N}$ & $\%$ & $\mathrm{n}$ & $\%$ \\
\hline Pengetahuan & 28 & 60,9 & 18 & 39,1 & 46 & 100 \\
$\begin{array}{l}\text { Rendah } \\
\text { Tinggi }\end{array}$ & 1 & 14,3 & 6 & 85,7 & 7 & 100 \\
\hline \multicolumn{1}{c}{ Jumlah } & 29 & & 24 & & 53 & 100 \\
\hline
\end{tabular}


Hilma. Faktor-Faktor yang Mempengaruhi Kejadian Skabies di Pondok Pesantren Mlangi Nogotirto Gamping Sleman Yogyakarta

Prevalensi yang didapatkan sebesar 4,261 dengan 1,205-3,049 artinya frekuensi dengan Confidence Interval (95\%) 0,684- kontak dengan penderita merupakan faktor 26,543 artinya tingkat pengetahuan belum risiko kejadian skabies.

tentu merupakan faktor risiko kejadian Distribusi responden berdasarkan

Tabel 3. Distribusi berdasarkan frekuensi kontak

\begin{tabular}{lcccccc}
\hline & \multicolumn{4}{c}{ Skabies } & \multirow{2}{*}{ Jumlah } \\
\cline { 2 - 5 } & \multicolumn{3}{c}{ Ya } & \multicolumn{2}{c}{ Tidak } & \multicolumn{1}{c}{} \\
\cline { 2 - 6 } & $\mathrm{N}$ & $\%$ & $\mathrm{~N}$ & $\%$ & $\mathrm{~N}$ & $\%$ \\
\hline Frekuensi & & & & & & \\
kontak & & & & & & \\
Tinggi & 15 & 78,9 & 4 & 21,1 & 19 & 100 \\
Rendah & 14 & 41,2 & 20 & 58,8 & 34 & 100 \\
\hline \multicolumn{1}{c}{ Jumlah } & 29 & & 24 & & 53 & 100 \\
\hline
\end{tabular}

Tabel 4. Distribusi berdasarkan tingkat higienitas

\begin{tabular}{lcccccc}
\hline & \multicolumn{4}{c}{ Skabies } & \multirow{2}{*}{ Jumlah } \\
\cline { 2 - 5 } & \multicolumn{3}{c}{ Ya } & \multicolumn{2}{c}{ Tidak } & \multicolumn{2}{c}{} \\
\cline { 2 - 6 } & $\mathrm{N}$ & $\%$ & $\mathrm{~N}$ & $\%$ & $\mathrm{~N}$ & $\%$ \\
\hline Higienitas & & & & & & \\
Buruk & 19 & 59,4 & 13 & 40,6 & 32 & 100 \\
Baik & 10 & 47,6 & 11 & 52,4 & 21 & 100 \\
\hline \multicolumn{1}{c}{ Jumlah } & 29 & & 24 & & 53 & 100 \\
\hline
\end{tabular}

skabies, karena dalam rentang Confidence Interval mencakup nilai 1.

Distribusi kejadian skabies dengan frekuensi kontak tidak langsung dapat dilihat pada Tabel 3 berikut ini.

Hasil analisis antara frekuensi kontak tidak langsung dengan kejadian skabies menggunakan uji Pearson Chi Square didapatkan $p$ value sebesar 0,008 yang berarti terdapat hubungan bermakna. Rasio Prevalensi yang didapatkan sebesar 1,917 tingkat higienitas dapat dilihat pada Tabel 4 berikut.

Hasil analisis antara higienitas dengan kejadian skabies menggunakan uji Pearson Chi-Square didapatkan $p$ value sebesar 0,4 yang berarti tidak terdapat hubungan bermakna. Rasio Prevalensi yang didapatkan sebesar 1,247 dengan 0,7322,123 artinya higienitas belum tentu menjadi faktor risiko dari kejadian skabies. 
Berdasarkan hasil wawancara dengan pengasuh PP An-Nasyath Mlangi didapatkan bahwa luas bangunan pesantren putra adalah $300 \mathrm{~m}^{2}$ dengan jumlah santri 28 sehingga setiap santri putra menempati luas bangunan $10,71 \mathrm{~m}^{2}\left(>7,5 \mathrm{~m}^{2}\right)$ berarti seluruh responden putra berada di bangunan yang tidak padat penghuni.

Sedangkan untuk luas bangunan pesantren putri adalah $350 \mathrm{~m}^{2}$ dengan jumlah responden 29 sehingga setiap santri putri menempati luas bangunan $12,06 \mathrm{~m}^{2}$ berarti seluruh santri putri berada di bangunan yang tidak padat penghuni.

Hasil perhitungan tersebut membuktikan bahwa variabel tingkat kepadatan hunian tidak memiliki hubungan yang bermakna dengan kejadian skabies di Pondok Pesantren An-Nasyath.

Hasil analisis regresi logistik menunjukkan frekuensi kontak merupakan variabel yang lebih memiliki hubungan bermakna $(p=0,013)$ dengan kejadian skabies dibanding variabel tingkat pengetahuan $(p=0,044)$. Selain itu, tingkat pengetahuan memiliki $\operatorname{Exp}(B)$ atau OR 0,087 dengan Confidence Interval 0,0080,932 yang artinya orang dengan tingkat pengetahuan tinggi mempunyai kemungkinan 0,087 kali lebih sering untuk menderita skabies dibanding orang dengan tingkat pengetahuan rendah. Sedangkan, frekuensi kontak tinggi memiliki OR 0,163 dengan Confidence Interval 0,39-0,679 yang artinya orang dengan frekuensi kontak tinggi mempunyai kemungkinan 0,163 kali lebih sering untuk menderita skabies dibanding dengan frekuensi kontak rendah.

Hasil analisis terdapat hubungan bermakna antara tingkat pengetahuan dengan kejadian skabies. Hal ini dikarenakan pengetahuan merupakan domain yang sangat penting untuk terbentuknya tindakan seseorang (overt behavior), setelah memiliki pengetahuan maka akan terbentuk sikap yaitu kesiapan atau kesediaan untuk bertindak selanjutnya terwujud suatu perilaku yang memerlukan faktor pendukung atau suatu kondisi yang memungkinkan antara lain fasilitas. Perilaku yang didasarkan oleh pengetahuan akan lebih langgeng daripada perilaku yang tidak didasari oleh pengetahuan ${ }^{6}$. Salah satunya dalam perilaku kesehatan terkait pencegahan penyakit skabies.

Penelitian serupa menunjukkan bahwa tingkat pengetahuan berhubungan terhadap perilaku pencegahan skabies pada ibu-ibu pemulung terhadap kejadian skabies anak di TPA Semarang dengan nilai $p=0,001$ $(p<0,05){ }^{7} \quad$ Hasil tersebut semakin memperkuat kesimpulan bahwa terdapat 
hubungan antara tingkat pengetahuan seseorang terhadap kejadian skabies. Pengetahuan yang tinggi tentang penyakit skabies akan membuat seseorang lebih berhati-hati dan menerapkan gaya hidup bersih sehari-hari sehingga diharapkan dapat menurunkan risiko kejadian skabies.

Rasio Prevalensi pada penelitian ini lebih dari 1 yaitu sebesar 4,261 namun Confidence Interval (95\%) yang didapatkan mencakup nilai 1 yaitu 0,684-26,543 artinya tingkat pengetahuan belum tentu merupakan faktor risiko kejadian skabies. Hasil ini berbeda dengan penelitian Azizah (2011) yang mendapatkan nilai Confidence Interval tidak mencakup nilai 1 yaitu 1.940 sampai 25.255 menunjukkan bahwa tingkat pengetahuan yang rendah merupakan faktor risiko kejadian skabies. Hal ini dapat dipengaruhi oleh 2 sebab, yaitu (1) tingkat pengetahuan memang bukan merupakan faktor risiko kejadian skabies atau (2) jumlah subyek yang diteliti kurang banyak, sehingga apabila dilakukan penambahan jumlah subyek maka akan mempersempit rentang Confidence Interva. ${ }^{8}$

Analisis antara frekuensi kontak tidak langsung dengan kejadian skabies didapatkan $p$ value sebesar 0,008 yang berarti terdapat hubungan bermakna antara frekuensi kontak dengan kejadian skabies.
Pada penelitian lain menunjukkan hasil bahwa tidak terdapat hubungan antara riwayat kontak tidak langsung dengan kejadian skabies, namun 4 hal yang dinilai untuk menentukan riwayat kontak tidak langsung dalam penelitian tersebut yaitu kebiasaan bergantian handuk, alat shalat, pakaian dan selimut, masih terdapat 1 hal yang berhubungan dengan kejadian skabies yaitu riwayat kebiasaan bergantian alat shalat dengan nilai $p=0007 .{ }^{10}$ Perbedaan hasil ini dapat disebabkan oleh tingkat kebiasaan responden sehari-hari terkait frekuensi kontak tidak langsung terhadap penderita skabies yang berbeda, seperti pinjam-meminjam alat pribadi. Pada Pondok Pesantren An-Nasyath masih banyak santri yang menggunakan alat-alat pribadi bersama-sama, seperti menggunakan jaket, mukena, selimut, handuk bahkan sabun mandi, karena santri belum mengerti bahwa perilaku tersebut dapat meningkatkan kejadian skabies.

Rasio Prevalensi yang didapatkan sebesar 1,917 dengan 1,205-3,049 artinya frekuensi kontak dengan penderita merupakan faktor risiko kejadian skabies karena dalam rentang Confidence Interval tidak mencakup nilai 1 .

Analisis antara higienitas dengan kejadian skabies didapatkan $p=0,4$ yang 
berarti tidak terdapat hubungan antara ekonomi, tingkat pengetahuan, kesalahan higienitas dengan kejadian skabies. diagnosis, hubungan seksual dan usia. ${ }^{2,14}$ Penelitian lain menunjukkan hasil yang Meskipun penelitian ini mendapatkan dimana kebersihan diri merupakan faktor risiko terjadinya skabies. ${ }^{5,12}$ Kebersihan juga merupakan faktor risiko kejadian skabies $^{11}$. Perbedaan ini dapat disebabkan oleh instrumen yang digunakan dalam penelitian di Pondok Pesantren An-Nasyat ini yaitu checklist berupa pertanyaan terkait sikap higienitas sehingga kurang tepat jika digunakan untuk mengetahui tingkat higienitas seseorang dengan kejadian skabies.

Hasil penelitian pada parameter kebersihan pribadi baik dan kurang baik, mendapatkan nilai $p=0,342$ artinya tidak ada hubungan yang bermakna antara kebersihan pribadi dengan kejadian skabies $^{12}$. Hal ini dapat disebabkan karena tingkat higienitas di pondok pesantren AnNasyath secara umum masih buruk, bukan hanya yang terserang skabies saja tetapi santri-santri yang tidak terserang skabies juga memiliki tingkat higienitas yang buruk. Hasil-hasil ini dapat membuktikan bahwa faktor yang mempengaruhi kejadian skabies bukan hanya dari faktor kebersihan diri saja, melainkan ada faktor-faktor lain yang mempengaruhi seperti tingkat Rasio Prevalensi lebih dari 1 yaitu sebesar 1,247 namun Confidence Interval-nya memiliki rentang $0,732-2,123$ artinya higienitas belum tentu menjadi faktor risiko dari kejadian skabies karena dalam Confidence Interval mencakup nilai 1.

Hasil penelitian menunjukkan bahwa semua responden tinggal di hunian yang termasuk kategori tidak padat dalam penelitian ini, sehingga kepadatan hunian tidak berhubungan dengan kejadian skabies. Hasil tersebut tidak sejalan dengan penelitian terdahulu yang mendapatkan nilai $p=0,001$ berarti terdapat hubungan yang bermakna antara kepadatan hunian dengan kejadian skabies. ${ }^{9}$ Hal ini disebabkan karena pada penelitian sebelumnya mengukur kepadatan hunian, namun hanya berdasarkan responden yang tinggal dalam kamar berjumlah 1-5 orang dengan responden yang tinggal dalam kamar >5 orang. Penelitian lain menunjukkan bahwa kepadatan hunian menyebabkan banyaknya kasus skabies. ${ }^{13}$

Hasil analisis regresi logistik
didapatkan bahwa variabel tingkat
pengetahuan dan frekuensi kontak dengan
penderita berpengaruh terhadap kejadian


skabies. Frekuensi kontak tidak langsung merupakan variabel yang lebih memiliki hubungan bermakana $(p=0,013)$ dengan kejadian skabies dibanding variabel tingkat pengetahuan $(p=0,044)$.

Penelitian ini memiliki beberapa keterbatasan yaitu yang pertama, terdapatnya recall bias pada variabel independen kepadatan hunian. Hal ini disebabkan saat dilakukan wawancara dengan pengasuh pesantren sebagai responden mengenai luas bangunan pesantren tidak berdasarkan catatan yang valid namun hanya menggunakan perkiraan dari responden.

Kedua, selama pemeriksaan dan penentuan diagnosis skabies oleh dokter dilakukan malam hari dengan penerangan ruangan yang kurang baik sehingga dimungkinkan akan mempengaruhi hasil ketepatan diagnosis skabies. Selain itu, pemeriksaan dilakukan di mushala putra untuk responden putra dan di mushala putri untuk responden putri yang merupakan ruangan terbuka untuk pemeriksaan, sehingga dimungkinkan ada responden yang kurang terbuka dengan keluhan gatalgatalnya karena malu diperhatikan oleh responden lain yang sedang mengantri di mushala.
Ketiga, variabel tingkat higienitas menggunakan checklist yang kurang tepat untuk mengukur tingkat higienitas responden, karena checklist tersebut lebih cenderung untuk mengukur sikap higienitas dari responden.

\section{KESIMPULAN DAN SARAN}

\section{Kesimpulan}

Dari hasil penelitian dapat disimpulkan bahwa ada hubungan bermakna antara tingkat pengetahuan dan frekuensi kontak tidak langsung dengan penderita terhadap kejadian skabies di Pondok Pesantren An-Nasyath dan tidak terdapat hubungan yang bermakna antara higienitas dan kepadatan hunian dengan kejadian skabies di Pondok Pesantren AnNasyath.

\section{Saran}

Berdasarkan hasil penelitian yang telah dilakukan dan ditemukannya faktorfaktor yang mempengaruhi kejadian skabies di Pondok Pesantren An-Nasyath, maka penelitian menyarankan kepada:

1. Pengasuh Pondok Pesantren AnNasyath

Meningkatkan upaya untuk menurunkan kejadian skabies dengan mengadakan penyuluhan serta 
menyediakan akses pelayanan kesehatan dengan baik.

2. Pengurus Santri Putra dan Putri

Menyusun jadwal kerja bakti untuk membersihkan lingkungan pesantren serta memberikan contoh perilaku hidup bersih dan sehat.

\section{DAFTAR PUSTAKA}

1. Siregar RS. Atlas Berwarna Saripati Penyakit Kulit (edisi kedua). 2005. Jakarta: EGC.

2. Handoko R P. Skabies dalam Ilmu Penyakit Kulit dan Kelamin (Edisi keenam), Badan Penerbit FKUI, 2010. Jakarta, 122-125.

3. Soemirat J. Kesehatan Lingkungan. 2011. Yogyakarta: Gadjah Mada University Press.

4. Saad. Pengaruh Faktor Higiene Perorangan Terhadap Kejadian Skabies di Pondok Pesantren An-Najach Magelang. 2008. Tesis FK UNDIP. Semarang.

5. Khotimah KK. Hubungan Sanitasi Lingkungan dan Hygiene Perorangan dengan Kejadian Skabies di Pondok Pesantren Al-Bahroniyyah Ngemplak Mranggen Kabupaten Demak. 2013. Skripsi FKM UNDIP. Semarang.

6. Notoatmodjo S. Kesehatan Masyarakat: Ilmu dan Seni. 2011. Jakarta: Rineka Cipta.

7. Azizah IN, Setyowati W. Hubungan Tingkat Pengetahuan Ibu Pemulung Tentang Personal Hygiene dengan
Kejadian Skabies pada Balita di Tempat Pembuangan Akhir Kota Semarang. 2011. Dinamika Kebidanan: vol.1(1).

8. Sastroasmoro S. Dasar-Dasar Metodologi Penelitian Klinis. 2011. Jakarta: CV. Sagung Seto.

9. Widyastuti K. Hubungan Higiene Perorangan, Riwayat Kontak Tidak Langsung dan Kepadatan Hunian Kamar dengan Kejadian Skabies Para Santri Putra Di Asrama Diponegoro Pondok Pesantren Krapyak Yogyakarta. 2008. Skripsi FK UII. Yogyakarta

10. Afraniza Y. Hubungan Antara Praktik Kebersihan Pribadi Dan Angka Kejadian Skabiesdi Pesantren Kyai Gading Kabupaten Demak. 2011. Skripsi FK UNDIP. Semarang.

11. Gatikasari A R. Hubungan Kebersihan Pribadi dengan Kejadian Skabies pada Santri Putra Kelas VII MTs Podok Pesantren Yayasan Amal Jariah Indonesia di Payaman Kabupaten Magelang. 2011. Skripsi FKUII. Yogyakarta.

12. Wang, C.H., Lee, S.C., Huang, S.S., Kao, Y.C., See, L.C., Yang, S.H. 2011. Risk factors for skabies in Taiwan. J.JMII (2012) 45, 276-280.

13. Ma'rufi, I., Keman, S. dan Notobroto, H.B. 2005. Faktor Sanitasi Lingkungan yang Berperan terhadap Prevalensi penyakit Skabies : Studi pada Santri di Pondok Pesantren Kabupaten Lamongan. Jurnal Kesehatan Lingkungan (2005); 2(1): 11-18.

14. Mansyur, M., Wibowo, A.A., Maria, A., Munandar, A., Abdillah, A., Ramadora, A.F., 2006. Pendekatan Kedokteran Keluarga pada Skabies Anak Usia Pra$\begin{array}{lll}\text { Sekolah. } & \text { MKI }\end{array}$ 